\title{
sciendo
}

Administration, vol. 69, no. 4 (2021), pp. 57-82

doi: 10.2478/admin-2021-0028

\section{Planning a Dublin-Belfast Economic Corridor: Networks, engagement and creating opportunities}

\author{
Eoin Magennis \\ Ulster University, Northern Ireland \\ Jordana Corrigan \\ Technological University Dublin, Ireland \\ Neale Blair \\ Ulster University, Northern Ireland \\ Deiric Ó Broin \\ Dublin City University, Ireland
}

\begin{abstract}
Cross-border cooperation on the island of Ireland has a long history, if often a limited scope. The emergence of statutory North/South bodies after the Belfast/Good Friday Agreement of 1998 added a new dynamic. This paper argues that the further development of the Dublin-Belfast Economic Corridor will require key stakeholders to engage widely, not only with a private sector whose rationale will be greater levels of commercial activity along the Corridor but also with others who will bring additional agendas into discussion, including sustainability and quality of life. Political engagement will also be critical to ensure that the top-down support, in terms of investment and alignment with other policy priorities, is present. The framework for this collaboration is already in place, something that was absent in the 1990s.
\end{abstract}


Actors and policy entrepreneurs who can bring together the different types of engagement on a cross-border basis are required.

Keywords: Corridor, cross-border, engagement, governance, policy

\section{Introduction}

Both the National Planning Framework (NPF; Department of Housing, Planning and Local Government, 2018) in Ireland and the Regional Development Strategy in Northern Ireland have objectives to support the Dublin-Belfast Economic Corridor (DBEC, or the Corridor). There is also a framework for cross-border cooperation in spatial planning agreed by the Department of Environment, Community and Local Government (Dublin) and the Department for Regional Development (Belfast). Framework for Co-operation: Spatial Strategies of Northern Ireland and the Republic of Ireland (2013) outlines a framework to facilitate opportunities for local government in both jurisdictions to work together and is recognised in the NPF as the continuing enabler for cross-border collaboration in spatial planning. The NPF continues to refer to corridors as a tool for encouraging balanced regional development on the east (DBEC) and west coast (Atlantic Economic Corridor) (Department of Housing, Planning and Local Government, 2018, p. 21). Despite such recognition and some considerable efforts, over many years, to develop corridor initiatives, there is scope for further reflection on many of the key challenges facing policy actors on the Corridor.

In this article we want to address one key challenge: that of achieving a consistent and sustainable engagement with initiatives to develop the Corridor. In March 2021 Dublin-Belfast Economic Corridor: Current Profile, Potential in Recovery and Opportunities for Cooperation was launched. At the event the chief executive of Belfast City Council, Suzanne Wylie, looked to the future and emphasised that 'the first steps will be political and public engagement by the network this year to refine priorities for a plan of work to grasp the opportunities identified in the report'. How this might be done forms the basis of this paper.

The sections which follow discuss the motivations for cross-border cooperation and corridor development generally, including the role of stakeholder engagement and the evolution of the corridor concept and engagement for the DBEC in the past and present. The discussion focuses on two key areas: (1) the role of private sector engagement 
and (2) the potential to build upon previous collaboration and operationalisation of existing frameworks.

\section{Cross-border cooperation and corridor development}

Motivations for cross-border cooperation and corridor development include the economy, strategic policymaking, infrastructure and, in more recent times, climate mitigation and adaptation. Corridor development reflects the five key dimensions of territorial governance: coordinating actions of actors and institutions, integrating policy sectors, mobilising stakeholder participation, being adaptive to changing contexts, realising place-based/territorial specificities and impacts (ESPON, 2015). Climate mitigation and adaptation could be drivers for cross-border cooperation and corridor development given that, for the first time in world history, 'all governance will occur under climate change' and there is a need to address how we understand and manage our relationship with the planet and ecosystems (Mintrom, 2019, p. 308). Innovative and entrepreneurial policy responses are required to address these challenges, and the advantages of crossjurisdictional collaborations in this regard are discussed in the literature (Mintrom, 2019, citing Kammerer \& Namhata, 2018, and True \& Mintrom, 2001). Those engaged in policy networks have been found to be more likely to achieve success in policy change: 'the external ties matter for idea generation, and the diffusion of ideas. The internal ties matter for actually making change happen' (Mintrom, 2019, p. 317).

Perkmann (2007) distinguishes between policy-driven and marketdriven cross-border integration. Policy-driven integration (a predominant feature in the European context) emerges in response to local and regional actors exploring the potential for cooperation, in response to regionalisation and globalisation, whereas market-driven integration directs activities in the case of persisting borders with emphasised cross-border differentials; for example, the US-Mexico border. Following an analysis of three cross-border regions, the structural conditions for policy entrepreneurship are considered generally to be shaped by political-administrative environments and are impacted positively by a higher level of municipal autonomy, which builds organisational competencies in cross-border policies and allows for the exploitation of opportunities. Perkmann (2007, p. 876) suggests that this policy entrepreneurship and organisation building are critical to creating 'durable local action in the multilevel governance 
framework'. The policy entrepreneurial role faces a challenge in formalising cross-cutting policies across organisations in vertically governed public organisations. This results in a need for strategies to integrate policy using elements of formal and informal actions, with vertical and horizontal governance logics (Svensson, 2019, p. 1213).

That said, cross-border cooperation on the island of Ireland has a long history, if often a limited scope since the 1920s and, in particular, the 1960s (Kennedy, 2000). Tannam (1999, p. 199) attributes the limitations in cooperation between 1980 and 1996 to the conditions of 'bounded rationality'. The mid 1980s brought cooperation in the areas of geographic necessity; for example, the catchment area of the Erne Waterways and local networking within border communities (Birrell, 2006, p. 251). The major influences on increased cooperation between local authorities in the last thirty years are political stability and improved relationships, the supports provided through a range of EU initiatives and the emergence of 'facilitating mechanisms' in the form of NGOs to support cross-border cooperation in local government; for example, Cooperation Ireland (Birrell, 2006; O'Dowd et al., 2007). In addition, the emergence of statutory North/South bodies after the Belfast/Good Friday Agreement of 1998, such as InterTradeIreland or Waterways Ireland, added a new dynamic (Coakley et al., 2007; Magennis, 2012). Cross-border cooperation has to be considered in the context of differing institutional and governance structures and functions, and legislative requirements. Local governments North and South have varying functions and relationships with central governments so motivation for engagement and alignment of working practices and objectives in this context is challenging.

A study undertaken by the Centre for Cross Border Studies (Birrell \& Hayes, 2001) found that the characteristics of cross-border cooperation included EU funding and a project-driven focus on economic development (with the acknowledgement that this is amenable politically (Tannam, 1999)). Intermediary bodies were found to be important, given that there were relatively few large-scale cross-border projects. So the involvement of local authority management is at the small scale, with activity concentrated in the border area. At the time of the study, twenty-five out of the then twenty-six district councils in Northern Ireland reported participation in cross-border collaboration (Birrell, 2006, p. 253). The extent to which this has led to greater levels of policy learning and transfer is a matter of debate, but there are signs that this process has begun (Magennis, 2007; Tannam, 2006). 
Cross-border corridors have the obvious additional considerations of varying institutional and governance structures and different cultural contexts. Scott (1999) describes how cross-border cooperation at the regional and local level is increasingly used to manage the complex processes of economic globalisation. Cross-border regionalism can be seen as:

part of a process of political regulation, operating at divergent spatial scales and describing a spatially integrated approach to problem-solving involving actors from local, regional and central levels. Alliances between cities, regions and local governments as a strategic response to allocative and distributive policies. (Scott, 1999, p. 606)

The literature notes that while the vertical and horizontal integration of all key stakeholders is acknowledged to be an important element of devising and implementing cross-border regional initiatives (Kaucic \& Sohn, 2021), it is clearly difficult to accomplish and it is clear that 'implementation varies strongly with respect to different national, regional and local institutional traditions as well as historical patterns of vertical and horizontal coordination' (Hall, 2008, p. 425). Scott (1999, p. 613) writes of the complexities of coordinating policy between different actors 'so therefore regional co-operation initiatives and networks appear in fact to be rather closed systems, with action primarily oriented towards influencing decisions within the immediate networks but with limited external (multiplier) effects'. Scott also draws attention to the fact that private sector participation in border region policies has been limited in the European experience by 'an administrative bureaucratic character'. This has contrasted with North America, where the experience has been that NGOs play an important role in promoting cross-border environmental policies. Hansen \& Serin $(2010$, p. 223) observe that, in relation to the Øresund regional initiatives, 'traditional national and regional territorial institutions have endured throughout the process and continue to play an important role in policy making'. However, they highlight the key role of cross-border network organisations, often civil society networks, and how these have played an important role in defining problems, but also 'through concrete participation in the problem-solving arena' (Hansen \& Serin 2010, p. 224). The role of the private sector in regional futures has been reviewed more recently in Harrison (2020), which is discussed later. 
Despite the increasing prevalence of cross-border initiatives, Scott (1999, p. 607) posits that it is unlikely that we will see the consolidation of institutional forms or cooperation modes in this regard due to the fact that cross-border regionalism is 'context-sensitive, conditioned by degrees of regional self-awareness, local identities, ideological discourses and the material co-operation incentives generated by interstate integration processes'. The contention is supported by more recent research (Kaucic \& Sohn, 2021; Wachsmuth \& Kilfoil, 2021).

Hall (2008, p. 423) discusses the Øresund cross-border region and describes the project as being characterised by:

a relatively closed network of public agencies, chaired by a few leading politicians and senior public officials. Their strategies of regional integration emphasise individual consumption instead of public participation, and their formal representative position is unsettled.

Hall's analysis explores questions of democracy, competency, legitimacy and accountability across actors and stakeholders in this context of multilevel governance.

It is recognised that the designation of a corridor in public policy does not necessarily lead to the implementation of a formal strategy. Potentiality and partnership are critical factors for success and the partnership aspect can be challenging in corridor development (Schönweitz, 2008, p. 91). The definition of the corridor is also a critical component for successful corridor development. Agreeing the geography and administrative structures of the corridor are essential to providing a framework for strategy or plan development.

In many cases the spatial definition of the corridor can be driven by the proponents of the corridor, i.e. national and local governments and the private sector. The public sector plays a role in infrastructure development and regulation of services, which creates opportunities for increased trade and enhanced public sector competitiveness, while the private sector is predisposed to developing new markets and maximising efficiencies in their supply chains and trade costs (Kunaka $\&$ Carruthers, 2014). The success of the corridor is therefore dependent upon the effectiveness of collaborations and coalitions to increase productivity. How the stakeholders (institutional and economic) work to manage a corridor is also a key dimension to the definition of a corridor (Kunaka \& Carruthers, 2014). 
Yarwood (2006b) describes the absence of a clear understanding of the DBEC. He outlines the consideration of its 'concrete configuration' as opposed to its economic function. A series of charrettes with schools of planning produced a hypothetical regional plan for the DBEC containing four general characteristics: a multimodal movement spine, integration of land use and activity with movement interchanges, compact development to retain community identity and reduce sprawl, and promotion of a polycentric settlement strategy. While this work resulted in a series of clearly illustrated maps, Yarwood (2006b) concludes with a summary of the importance of, and difficulties associated with, implementation. He notes that implementation may be 'impossibly difficult' for a number of reasons but mentions two reasons as being of particular merit. The first reason is the parochial nature of Irish politics, arguing that 'the greater the cooperative vision entailed by the scale of the idea, the less likely is it that the necessary teamwork could arise' (Yarwood, 2006b, p. 275). The second reason is financing and cost recovery. Yarwood suggests that for this reason a bottom-up approach to implementation is favourable. However, he notes the absence of leadership at local authority level to 'wave the corridor flag' and closes with the forecast that 'A corridor will be implemented in Ireland only with strong, albeit informal, cross-party political leadership from the top down, allied to a grass-roots support movement, probably led by the business type, which would probably start by commissioning a visionary study, deeper and richer than anything we have been able to produce in this book' (Yarwood, 2006b, p. 276).

The legal and regulatory context of corridors is outlined in Kunaka \& Carruthers (2014, p. 74), whereby 'collaboration' is defined as the highest level of decision-making (political alliances between heads of state, parliaments), 'cooperation' is mutual support (ministries and agencies) and 'management' refers to the effective running of the corridor. Corridor development requires all levels of government to be involved to ensure that strategic policymaking, infrastructure investment and fiscal leverage (where appropriate) are coordinated for maximum effect. Kunaka \& Carruthers (2014, p. 23) state that

multisectoral representation and participation of the private sector are sine qua non conditions for successful trade and transport corridors. A corridor is therefore a spatial structure for overcoming the fragmentation of legal, institutional, physical, and practical boundaries. 
Corridor management is a complex process requiring consistent engagement with relevant institutions to promote and facilitate collaboration. It is as much about relationships and trust as it is about ensuring services and infrastructure are operational. Coordination of activities is challenging and time-consuming as consensus and consultation are prerequisites to ensure that actions are acceptable to all involved. Institutional and administrative arrangements can clarify who makes the decisions and who is responsible for failures (Kunaka \& Carruthers, 2014, p. 94).

Wachsmuth \& Kilfoil (2021, p. 64) question the 'logic of regional collective action', referring to Tilly's (1985) definition of collective action as 'the conditions under which groups of social actors collaborate, either durably or sporadically, to achieve common goals'. They make the pertinent point that there is always the possibility of not taking collective action, which leads to the question of 'why work collectively at all?' (Wachsmuth \& Kilfoil, 2021, p. 65). Furthermore, de Vries \& Priemus (2003, p. 232) make the very important point that the issue of who to involve or engage is key: too few and governance falters; too many stakeholders and issues diminish the chance of success. Achieving the correct balance is a critical step.

\section{The role of stakeholder engagement}

Over the course of the past fifty years the role of economic actors in urban and regional governance can be characterised by four distinct, but interrelated, phases: growth machines, growth coalitions and urban regime theory (1970-1980s); new regionalism (1990s); global city regionalism (2000s); and competitive multi-city regionalism (2010s) (Harrison, 2020). Growth machines, sometimes referred to as growth coalitions or regimes, described the collaboration of actors local governments, real estate, construction and utility companies - to maximise profit from land-use intensification (Harrison, 2020, citing Molotch, 1976, and Stone, 1989), and formed the precursor to the theory of urban entrepreneurialism (as defined by Harvey, 1989). The interest in business engagement in economic development translated to the regions in the 1990s with new institutional arrangements of state, business and civic actors promoting business interests, political coalitions and state capacities at the regional scale. Global city regionalism followed in the 2000s with a move away from state-led regionalism to more networked and open, less governmentalised spaces for coalition formation for labour market expansion. More 
recently, research has emerged on a new spatial logic of regionalism at mega or multi-city scale - 'infrastructure regionalism' - which argues that when the logic for regionalism is extended beyond a single metropolitan area, the cooperation incentivised at the city-regional scale by the common labour market becomes nil and void (Harrison, 2020). Multi-city regionalism is evident in the 'Northern Powerhouse' initiative in the UK, which seeks to provide a counterbalance to London and promote spatial rebalancing. While the efforts here are promoted and coordinated centrally by the state, there is also significant influence from the lobbying of economic actors, i.e. support in the media, lobbying of ministers, to less visible measures to influence government policy (staff secondments, funding think tanks) (Harrison, 2020, p. 7). In contrast, multi-city regionalism is emerging from the ground up with Peel's Atlantic Gateway, which is a private sector vision for the Manchester and Liverpool city regions. The premise here is that investment in infrastructure is key to unlocking the regions' potential, and while the origins of this initiative lie with one company, 'Peel', it has been 'institutionalised to become a 'space of governance with its own partnership board' (Harrison, 2020, p. 7).

Waite (2021) explores the economic system of Edinburgh and Glasgow and describes four key themes which 'sit behind the waxing and waning of policy interest in the polycentrism for EdinburghGlasgow: competitiveness and investment; infrastructure and planning; local and national politics; and cultures of deal-making and city regionalism'. The competitiveness theme centred around the 'collaborate to compete' mantra in response to policy understanding that cities needed scale to attract investment, retain key sectors and achieve the 'collaborative success' between the universities across the two cities (Waite, 2021, p. 7).

In relation to stakeholder engagement, the motivations can include influence on strategic policymaking, infrastructure investment, fiscal leverage coordination for maximum effect, sector-specific prioritisation and development. Furthermore, a number of other considerations have the potential to impact on stakeholder engagement in corridor management and need to be examined:

- At which spatial scales are the corridor management's loci of coordination and implementation: national, regional or local?

- What values are driving the corridor management initiative, e.g. infrastructure investment versus collaboration? 
- Is there variable engagement on different sectoral areas - e.g. tourism, agriculture - and scope for policy mobilities?

- The corridor as a politico-strategic concept is 'constitutively ephemeral: it exists on few maps and corresponds to few institutional frameworks' (Wachsmuth \& Kilfoil, 2021, p. 64). This point is particularly relevant as a number of iterations of the corridor's development trajectory are strongly linked with road and rail infrastructure.

Broadhurst et al. (2021) discuss the growing popularity of subnational governance across Europe and the notion of 'place-based leadership'. Their research contributes to the understanding of multi-actor collaborations and why some partnerships are more successful than others. Partner engagement is found to be challenging, and the relationship between public and private interests is a complex one whereby a lack of trust between local authorities can lead to an imbalance in representation within a board structure of public and private actors (tilted in favour of the sector). A history of collaboration fosters trust and builds effective working relationships between partners, whereas a lack of pre-existing collaboration is a disadvantage. Notwithstanding this, it is also acknowledged that newly joining partners need time to get up to speed within established collaborations, and that engagement by private interests can be a significant time commitment.

Harrison (2020), citing Mayer (2008, p. 416), states that 'it is never the spatial form that acts, but rather social actors who, embedded in particular (multidimensional) spatial forms and making use of particular (multidimensional) forms, act'. He argues that there is an increased importance of businesses and capital interests in regional development, that studies of regional governance 'are guilty of talking about business as opposed to talking to business', and that the 'intellectual challenge is not what and where these spaces are emerging, but questions of agency (who the actors are), process (how they are mobilizing) and interest (why they are engaging)' (Harrison, 2020, p. 17).

A key lesson from Øresund is that the involvement of private sector interests in a sustainable and coherent manner is difficult to achieve. The proposition of an open or relatively open network, as opposed to the closed network highlighted by Hall (2008), is deeply problematic as the motive force for such initiatives is often politico-institutional; for example, depending on funding that is aimed at local and regional 
public agencies, rather than being designed to foster inclusive or broader stakeholder engagement - in particular, private sector participation. Evidence from other border regions in Europe (Spain/Portugal and Estonia/Finland) suggests that if informal networks and linkages are weaker than formal ones, then cooperation proves less sustainable outside a short-term window (GonzálezGómez \& Gualda, 2014).

\section{The DBEC: Concept and engagement, past and present}

The idea of a DBEC has a history going back three decades and is closely associated with Sir George Quigley, the former Permanent Secretary of Northern Ireland's Department of Finance and Personnel (1982-8) and then chairman of Ulster Bank. Quigley first publicly called for the development of the DBEC in a speech entitled 'Ireland: An Island Economy' to the Confederation of Irish Industry (now IBEC) in February 1992, when he was president of the Confederation of British Industry in Northern Ireland (Quigley, 2015). In his speech he captured some of the enthusiasm to pursue cross-border cooperation that had appeared at that time as the fledgling peace process took hold. American business consultants, economic researchers, university heads and business organisations were all exploring opportunities to work together, often for the first time (Quigley, 2015, pp. 54-8). The idea, as presented in 1992, was based on the belief that higher levels of growth for whole regions could result with better interaction between growth centres.

The idea of an economic corridor between the two major cities on the island, Dublin and Belfast, was quickly adopted by the new IBECCBI Joint Business Council, which commissioned a feasibility study for developing such a corridor (Coopers \& Lybrand/Indecon, 1994). The study reviewed exemplar case studies - including Windsor-Quebec, Vancouver-Seattle and the M4 (London-Swansea) Corridor in England - and concluded that all of these had similar requirements for their development. Good transport infrastructure and scheduled connectivity between centres, clusters of export-oriented businesses (in particular, manufacturing firms) which collaborate with each other and with government agencies and other actors, and access to bank and risk capital were all identified as prerequisites. The study profiled the regions covered by the DBEC and concluded that, with the provision of similar conditions, a similar success story could develop. Following publication of the study in 1994, the Joint Business Council 
established a task force, largely made up of private sector actors, with the jobs of promoting the recommendations in the feasibility study, primarily in the transport field but also in developing a greater level of trade and business linkages.

The rationale for developing the Corridor at this time was a mix of private sector enthusiasm (against the background of the opening of the EU Single Market on 1 January 1993 and the peace process in Northern Ireland that would lead to ceasefires in 1994) and the plans for improvements of both the road and rail links between Dublin and Belfast. The latter, with EU funding essential, moved slowly through the 1990s and 2000s with the bypasses of Dunleer, Drogheda and Dundalk, and then Newry, and the 1997 upgrade of the Enterprise rail service being milestones in transport connectivity between the two cities. These improvements were the result of conscious developments by the Irish governments and its partners on the other side of the border - first the UK government through the Northern Ireland Office and then the devolved Northern Ireland Executive - and all made possible by significant Cohesion Fund, European Regional Development Fund and Interreg financial assistance over two decades. At the same time those involved in the promotion and lobbying work for the Corridor, largely private sector actors, made a point of saying they were 'kicking politics out of it' (Hayward \& Magennis, 2014, p. 166).

This was to prove difficult, not least because the original claims could be seen as over-optimistic (Birnie \& Hitchens, 1997). For one thing, transport infrastructure on its own would not be a condition for a successful economic corridor, had not been in the North American examples and would not be in the Øresund region later. In addition, there was arguably too much of a focus on cross-border trade. Claims that the value of trade in manufactured goods could be rapidly trebled from $£ 1$ billion to $£ 3$ billion were fanciful given the size of the two markets. This level would not be reached until 2017. The allied claim of 75,000 additional jobs from an increase in cross-border trade was equally difficult to stand over (Coopers \& Lybrand/Indecon, 1994). However, it is also important to understand that what was seen at stake in the early 1990s was that the island of Ireland could fall further behind other European economies, and the ambition to focus both public and private initiative on the economic corridor as a tool to improve wider competitiveness had much to recommend it.

Since then, there has been progress in many areas along the Corridor, much of this enabled by investment from the Irish 
government, UK government, NI Executive and EU Structural Fund sources. As noted above, the productive infrastructure (in particular, the road and rail connections between Dublin and Belfast) is vastly improved relative to the 1990s and now carries many more people than was the case then. Education infrastructure and research centres have also grown significantly over the same period along the Corridor, partly as a result of the general expansion of further and higher education in recent decades and partly because of the location of a growing population in the eastern seaboard of the island. A similar picture can be provided for improvements in tourism offerings, and the expansion of ports and airports - in particular, Dublin. In parallel, there has been a consistent application of resources to expand trade and business development activities across the island which have a cross-border basis. In the 1990s this was primarily the work of the IBEC/CBI Joint Business Council and local chambers of commerce (all supported by EU funding). From 2000 InterTradeIreland took up this role as one of six new statutory cross-border bodies and has continued this work since. Two points can be made about this enabling of private sector initiative. First, it is not Corridor-focused as such, although proximity to the border has dictated in part the extent to which business actors have engaged in cross-border activity (Roper, 2007). Second, the activity remains premised on the basis of reducing barriers to enable cross-border trade and knowledge flows, and in keeping politics (and sometimes policy) out of it. In more recent times the work of InterTradeIreland, the Joint Business Council and other business organisations have been joined by two more recent Corridor additions: the M1 Corridor idea (from Dundalk and Drogheda Chambers in 2019) and the FinTech Corridor. In both these cases, private sector actors are to the fore, one being a promotion of place and the other the development of a particular sector or emerging cluster.

The importance of place to the Corridor, as whole and individual parts of it, has consistently given rise to local authority initiatives which have sought to find a focus for inter-council and cross-border cooperation. There are several examples of this from the first two decades of this century, all of which have involved either elected councillors, a wider engagement with different parts of civic society or both. The M1 Economic Corridor study (Indecon, 2010), commissioned by Fingal, Meath and Louth County Councils, would fall into this category, and looked at the potential growth of the full length of the road connection between Dublin and Belfast and the 
area $25 \mathrm{~km}$ to either side of this road. Business representative organisations (local chambers of commerce), central and local government bodies, and higher education institutes were all consulted for this report, which identified a series of potential infrastructure and tourism investments that could harness growth in the Corridor, and especially in the three council areas. A different type of engagement in March 2014 was brought about in the Lord Mayors' Forum when Dublin and Belfast city mayors held two conferences in the cities and a discussion on a train running between the two to produce a set of actions they hoped would be pursued, including greater levels of collaboration between public agencies in tourism promotion and attraction of FDI, improvement of the Enterprise rail service, and encouragement of higher levels of mobility of students, workers and entrepreneurs along the Corridor (KPMG, 2014). Infrastructure has been a consistent theme in these Corridor initiatives and others going back to the 1990s and the calls for completion of motorway and faster rail connections. The benefits of infrastructure improvements, greater accessibility and faster travel times can be summarised as greater levels of synergy (and efficiency) in the Corridor, more balanced regional development along it and better accessibility into it (International Centre for Local and Regional Development, 2009, p. 3). The Corridor has also been recognised (or lobbied for) as a key location for investment in infrastructure, not least in the areas of transport and energy, as a means of increasing growth across the whole island (Irish Academy of Engineering, 2016).

A final, important example of local initiative has probably been one that has proven most long-lasting: the 'Newry/Dundalk Twin City' concept. The concept has given life to both a number of different research reports and strategy documents and to the 2011 memorandum of understanding between the then Newry and Mourne District Council and Louth County Council. In this case a structure of joint senior management teams, working groups of council officers and an advisory forum of elected councillors, business representatives and central government officials was established to take forward a joint work programme (International Centre for Local and Regional Development, 2009; McArdle, 2013). All of this has operated alongside the parallel East Border Region (EBR) cross-border network of elected councillors and a secretariat with strong experience since the 1980s in securing and administering EU funding across a range of thematic areas, including economic development, tourism, energy and environment infrastructure and management, and local 
authority cooperation. The EBR has recently restated its central place in any Corridor initiative with a new charter which seeks to position the border region as a smart, competitive, sustainable and inclusive place (EBR, 2021).

The concept of the Corridor has not been without its critics since the 1990s. The earliest forms of critique questioned the benefits or the scale of these as claimed at the time (Birnie \& Hitchens, 1997; Teague et al., 1997). Later questions centred on whether the Corridor could be called a 'mythical beast', something that had potential as an idea but had yet to find a form (Yarwood, 2006a, p. 3). The point that was being made in this analysis was that:

For sure it [the Corridor] is on the agenda, but there are few, if any signs of serious commitment at a high level and no programme of coordinated action. There is no corridor plan or even the prolegomena for a plan. (Yarwood, 2006a, p. 8)

While the idea of the Corridor has been a significant presence in spatial plans (Williams et al., 2006) and in several national development plans from the Irish government (e.g. Government of Ireland, 2021, p. 164), this still does not feel like a concerted plan. Perhaps a reason for this has been the concern, expressed in the 1990s, about whether the improvements and growth in the DBEC were merely a fact of geography (i.e. this was where they happened) or whether the Corridor provides a dynamic and innovative milieu for such growth to happen (Bradley, 1997, p. 107). Perhaps, too, the Corridor has remained an idea rather than a plan backed by serious local and national engagement. The reasons for the inertia speak to wider issues of cross-border cooperation remaining incremental and pragmatic, as opposed to ambitious, in order not to provoke political opposition. The slow progress in cross-border trade and all-island business cooperation since the 1990s reflects the consistent application of time and resources need to develop networks, especially away from the border counties themselves. How far Brexit and the resulting Northern Ireland Protocol will change this reality, and reorient commercial patterns, will be something to monitor in the next few years.

The most recent initiative to promote and perhaps provide the DBEC idea with some leadership has come once more from local government, namely a new network of eight council areas along the motorway linking the two cities with two universities. This began in the 
autumn of 2017 with an initial focus on identifying what benefits might arise from introducing a faster and more frequent rail connection between Belfast and Dublin - what became known as the 'high-speed rail' option. In April 2018 the initiative developed further as the local authorities invited two universities (Dublin City University and Ulster University) to research a socio-economic profile of the Corridor and the best prospects for collaboration. Although there had been previous economic profiles (Coopers \& Lybrand/Indecon, 1994; Indecon, 2010), the context was now very different, not least because of Brexit and the lack of clarity (in 2018) about the future position of Northern Ireland within the EU Single Market (Murphy, 2018; Ó Beacháin, 2018).

An important part of the research project was to begin a process of engagement and consultation with stakeholders about the challenges or opportunities along the Corridor. An initial workshop was held in September 2018, which was attended by the local authorities and the academic partners. The purpose of the event was to identify initial areas/priorities for collaboration which could be further explored in the research. Each local authority presented an overview of their own local strategic ambitions for economic and sectoral development. They also identified past and potential future collaborations with other stakeholders. The councils were asked to consider which areas should be prioritised for cooperation across the Corridor regardless of whether the council had remit in this area or not. The academic partners presented examples of cross-border collaborative frameworks developed in the past and a series of roundtable discussions followed which addressed the questions of:

- What is the rationale for collaboration?

- What are the challenges, constraints or opportunities for collaboration?

- How should we define the geography of the Corridor?

- What is the future of the Corridor?

In parallel to the engagement a fledgling governance structure has been developed to involve the eight councils and two universities. This structure is quite close to the model used in the Newry/Dundalk Twin City work, with a chief executives' group, a working group at director level within the organisations and an oversight group of councillors elected by each of the eight local authorities. The councillors have generally been elected from among those active in strategic policy 
committees in the South and those active on economic development, regeneration and growth committees in the North, and, in a few cases, to reflect the geography of local councils. The first meeting of the oversight group was due in November 2021 and will be an important part of broadening collaboration beyond a technocratic layer, though it will be only an initial step in trust building that will need further time and resources (Broadhurst et al., 2021).

Beyond the circle of local government actors there has, to date, been a limited amount of wider engagement with private sector actors, central government and local stakeholders. The research involved a series of consultations with other government agencies (including cross-border bodies), and private and third sector representative bodies. This was intended, firstly, to prompt discussion on what consultees felt would be potential areas/sectors for growth on the Corridor and where they believed additional intra-jurisdictional cooperation would add benefits to developing the priorities. In addition, the intention was to reintroduce the idea of the DBEC into a wider discussion about the future of cross-border economic development and the place of geographical places or regions within that. After the report was finalised a series of presentations were made to central government actors, and then a wider audience as it was launched online in March 2021.

Several themes found their way to the fore in these engagements, including:

- identity and branding as an early action;

- consistent time energy and resources to nurture the Corridor;

- recognition that local actions can deliver strategic objectives (innovation centres, skills strategies);

- medium- to long-term strategy;

- early wins can help cement the partnership;

- challenges: Brexit, climate change, housing, skills, business start-up rate, population.

\section{Discussion}

\section{Role of private sector engagement}

The research on private sector engagement in cross-border initiatives, though limited, highlights a number of pertinent issues for the development of the DBEC. The first relates to the nature of both the Irish and UK approach to public governance and the consequences for 
cross-border collaboration. In an analysis of private sector engagement in the EU Interreg programmes in the 1990s, Lagana (2020, p. 105) argues that the 'highly centralised nature of the Irish and UK administrations, together with the political symbolism of cross-border cooperation in the Irish border regions' tended to hinder an authentic involvement of the private sector in cross-border initiatives. Ilbery \& Saxena (2011, p. 1151) also note, despite a less politically contested context, a similar dynamic in collaborative tourism initiatives in the English-Welsh border region.

Heretofore, private sector actors, including business representative organisations, were aware of the opportunities and constraints offered by shared EU membership in the 1990s and started to 'act more strategically in order to gain a more active role in the processes of public policymaking' (Lagana 2020, p. 107). It remains unclear what structured processes currently exist to facilitate intra-private sector collaboration, though Hayward \& Magennis (2014) note, in their analysis of the 2000s, a number of interesting developments, as well as developments between the private sector and public bodies along the DBEC - in particular, local governments. At local government level i.e. county, city or district council level - there are a variety of modes of engagement between the particular local government and the local private sector. This is not unexpected and follows the experience of a wide variety of cross-border initiatives across the EU where 'bilateral partnerships are the dominant type of cooperation existing between local governments and NGOs' (Kurowska-Pysz, 2016, p. 230).

The second issue that bears analysis relates to evidence that the drivers of cross-border cooperation will have different roles depending on the nature of cooperation, whether education and training, small and medium-sized enterprises and entrepreneurship, or infrastructure (Basboga, 2020). Similarly, actors will have differing capacities and tendencies to lead or follow, be more collaborative or competitive. The 'connectivities' between political and economic actors are also difficult to measure, alter and utilise, suggesting the potential for inclusion/exclusion of actors (Herrschel, 2009). This clearly reaffirms the idea that policies and structures designed to engender crossborder collaboration cannot be designed in a 'one-size-fits-all' manner and that a variety of configurations might be appropriate depending on the thematic stakeholders and representativeness of existing networks. This leads to a related challenge: clarifying the purpose of private sector engagement. Is it focused on a particular theme - for example, enterprise development or infrastructure or skills - or is it 
designed to facilitate a form of cross-border social dialogue (HornungDraus, 2021) with an emerging quasi-public body?

In the context of the DBEC it is recommended that particular attention and acknowledgement are paid to private sector perceptions of local-government-led initiatives, and that the focus of the crossborder collaboration includes a strong thematic element. This follows the insights of Hayward \& Magennis (2014, p. 170), who note that 'an emphasis on the shared, pragmatic goal of business growth and profit' is more likely to encourage engagement. In addition, it is suggested that the expectations and priorities of place-centred business representative bodies, such as chambers of commerce, and sectororiented business representative bodies are likely to be quite distinct, and cognisance should be paid to the various nuances. Finally, it is important to remember that in regions more complex and contested, local-level actors have been "proactive in establishing, nurturing and sustaining modes of governance and structures of engagement and collaboration that have levered considerable EU and non-EU resources and have enhanced local economies, living conditions and the natural environment' (O'Keeffe \& Creamer 2019, p. 168).

\section{Building upon previous collaboration and operationalisation of existing frameworks}

Considering options for the future development of the DBEC, and particularly the leadership role of local government, the degree of policy integration amongst stakeholders is an issue that will need to be addressed. There is a spectrum of potential outcomes from such a debate: policy cooperation, policy coordination and policy integration (Stead \& Meijers, 2009). As noted by Nadin et al. (2021, p. 793), policy integration involves 'more interaction between actors, more formal institutional arrangements and more resources'. Consequently, the conditions necessary for enabling policy integration require stakeholder commitment across a variety of measures. In general, policy alignment and integration are considered to be beneficial, particularly in the island of Ireland, cross-border context (e.g. Rafferty $\&$ Blair, 2020). Whilst structure, process and legislation are essential ingredients for delivering policy integration, as expressed by a placebased leadership model for regional partnerships (see Broadhurst et al., 2021), the 'operationalisation' of these measures is equally important. In the context of the DBEC, this includes local government officers and other institutional facilitators situated within existing networks (e.g. EBR), central governments (e.g. North-South 
Ministerial Council) and the Eastern and Midland Regional Assembly (EMRA). With the complexities that exist in the DBEC, the role of the 'policy entrepreneur' (Svensson, 2019) will be central, working across formal and informal spaces as 'boundary spanners' and 'brokers' that can transcend organisational barriers.

We would propose that, whilst the emerging DBEC governance structures are a new expression of collaboration amongst stakeholders, a significant portion of the policy framework necessary to operationalise the concept already exists. There is a strong case for spatial planning to be at the core of the DBEC, particularly from the perspective of the Corridor as a functional geography that goes beyond purely economic ties to include socio-spatial relations (Rafferty \& Blair, 2020). Indeed, functional geographies 'represent a post-industrial, post-territorial concept for moving beyond the traditional confines of bounded territorial administration to govern more "messy" geographies that better reflect contemporary crossjurisdictional functional interdependencies, particularly given the uncertainties of Brexit' (Rafferty \& Blair, 2020, p. 189).

The case for spatial planning is founded on the established interjurisdictional agreement, the Framework for Co-operation (Department of Regional Development NI \& Department of Environment, Community and Local Government, 2013) noted earlier. Utilising this agreement, which is still 'in play' post Brexit, means there is not a requirement to instigate a new instrument that otherwise would demand time and resources to develop. There are four key justifications for a spatial planning focus. First, spatial planning is a common policy area across a range of public sector institutions linked to the DBEC, which, although having differing roles, provide a shared agenda around which actors and agents can coalesce. For example, each of the eight local councils have a legal responsibility as 'planning authorities', including development planning and development management; EMRA has a regional spatial planning duty; and networks such as EBR are involved in the outworking of spatial planning to promote development of the crossborder region. Second, and reflecting on the potential for policy integration and the role of policy entrepreneurs, planners can be understood as 'boundary spanners' (e.g. Rydin, 2021; Saldert, 2021). Given the complex institutional and regulatory environment of the DBEC, spatial planners are ideally placed - both by experience and by the nature of the profession - to work in between and with the range of stakeholders. Third, spatial planning is able to operate in the 
context of 'fuzzy boundaries' (Allmendinger \& Houghton, 2009; Walsh, 2015; Zimmerbauer, 2018), which, given the political sensitivities associated with the DBEC, in Northern Ireland at least, could provide the means to step beyond barriers that would otherwise exist with policymaking and decision-making in fixed geographic and administrative boundaries. Fourth, place-based collaboration already operates in the Border region through the Strategic Alliance between Newry, Mourne and Down Council and Louth County Council. Whilst this is more closely aligned to service delivery and 'community planning', as expressed in Northern Ireland, the Strategic Alliance is rooted in the 'Twin City Region' concept (International Centre for Local and Regional Development, 2009). This is therefore a demonstration of what is achievable in terms of identifying and operationalising pragmatic solutions to development challenges on the Corridor.

\section{Conclusion}

In 2006 the architect and planner John Yarwood made the point that the DBEC would only begin to be implemented when a top-down, cross-party political leadership met a bottom-up support movement, probably with private sector leadership (Yarwood, 2006b, p. 276). He predicted the work would begin with a visionary study, perhaps not unlike that which the local council network is beginning to discuss. This article suggests that this implementation will require the new network to engage widely, not only with a private sector whose rationale will be greater levels of commercial activity along the Corridor but also with other stakeholders who will bring other agendas into discussion, including sustainability and quality of life. Political engagement will also be critical to ensure that the top-down support, in terms of investment and alignment with other policy priorities, is present. The framework for this collaboration is already in place, something that was absent in the 1990s when Sir George Quigley first raised the idea of a Corridor. What is equally needed are the actors and policy entrepreneurs who can bring together the different types of engagement on a cross-border basis. Without these, there remains the risk of the Corridor idea failing for having a missing link. 


\section{References}

Allmendinger, P., \& Houghton, G. (2009). Soft spaces, fuzzy boundaries, and metagovernance: The new spatial planning in the Thames Gateway. Environment and Planning A, 41, 617-33.

Basboga, K. (2020). A theme-based analysis of the intensity of cross-border cooperation across Europe. Journal of Borderlands Studies. doi: 10.1080/08865655.2020.1833230

Birnie, E., \& Hitchens, D. (1997). The potential for a Belfast-Dublin Economic Corridor. Australasian Journal of Regional Studies, 2 (2), 167-87. Birrell, D. (2006). Local authorities and managing cross border projects. In J. Yarwood (Ed.), The Dublin-Belfast Development Corridor, Ireland's megacity region? Aldershot: Ashgate.

Birrell, D., \& Hayes A. (2001). Cross-border co-operation in local government development, management and reconciliation. Armagh: Centre for CrossBorder Studies.

Bradley, J. (1997). Exploring long-term social and economic consequences of peace and reconciliation in the island of Ireland. In Forum for Peace \& Reconciliation: Consultancy Studies, 4. Dublin: The Stationery Office.

Broadhurst, K., Ferreira, J., \& Berkeley, N. (2021). Place leadership: Developing a model to guide regional partnerships. Regional Studies, 55 (3), 556-67. doi: 10.1080/00343404.2020.1836343

Coakley, J., Ó Caoindealbháin, B., \& Wilson, R. (2007). The operation of the North-South implementation bodies. In J. Coakley \& L. O'Dowd (Eds), Crossing the border: New relationships between Northern Ireland and the Republic of Ireland (pp. 31-60.). Dublin: Irish Academic Press.

Coopers \& Lybrand/Indecon. (1994). A corridor of opportunity: Study of the feasibility of developing a Dublin-Belfast Economic Corridor. Dublin \& Belfast: IBEC and CBI NI.

Department of Housing, Planning and Local Government. (2018). Project Ireland 2040: National planning framework. Dublin: Department of Housing, Planning and Local Government.

Department of Regional Development NI and Department of Environment, Community and Local Government. (2013). Framework for co-operation: Spatial strategies of Northern Ireland and the Republic of Ireland. Retrieved from https://www.infrastructure-ni.gov.uk/sites/default/files/publications/ drd/spatial-strategy-framework.pdf [28 October 2021].

de Vries, J., \& Priemus, H. (2003). Mega-corridors in North West Europe: Issues for spatial governance. Journal of Transport Geography, 11, 225-33.

East Border Region. (2021). Ireland/Northern Ireland charter and protocols. Newry: East Border Region.

ESPON. (2015). European towns and territorial cohesion. Retrieved from https://www.espon.eu/topics-policy/publications/maps-month/europeantowns-and-territorial-cooperation [28 October 2021]. 
Gonzaléz-Gómez, T., \& Gualda, E. (2014). Cross-border networks in informal and formal cooperation in the border regions Andalusia-Algarve-Alentejo and Estonia-South Finland. European Planning Studies, 22 (7), 1407-24. doi: 10-1080/09654313.789487

Government of Ireland. (2021). National development plan 2021-2030. Dublin: Government of Ireland.

Hall, P. (2008). Opportunities for democracy in cross-border regions? Lessons from the Øresund region. Regional Studies, 42 (3), 423-35. doi:10.1080/00343400701281592

Hansen, P., \& Serin, G. (2010). Rescaling or institutional flexibility? The experience of the cross-border Øresund region. Regional and Federal Studies, 20 (2), 201-27. doi: 10.1080/13597561003731646

Harrison, J. (2020). Seeing like a business: Rethinking the role of business in regional development, planning and governance. Territory, Politics, Governance. doi:10.1080/21622671.2020.174320

Harvey, D. (1989). From managerialism to entrepreneurialism: The transformation in urban governance in late capitalism. Geografiska Annaler. Series B, Human Geography, 71 (1), 3-17. doi: 10.2307/490503

Hayward, K., \& Magennis, E. (2014). The business of building peace: Private sector cooperation across the Irish border. Irish Political Studies, 29 (1), 154-75. http://dx.doi.org/10.1080/07907184.2013.875896

Herrschel, T. (2009). City regions, polycentricity and the construction of peripheralities through governance. Urban Research and Practice, 2 (3), 240-50. doi: 10.1080/17535060903319103

Hornung-Draus, R. (2021). Cross-border social dialogue from the perspective of employers. European Labour Law Journal, 12 (1), 83-94.

Ilbery, B., \& Saxena, G. (2011). Integrated rural tourism in the English-Welsh cross-border region: An analysis of strategic, administrative and personal challenges. Regional Studies, 45 (8), 1139-55.

Indecon. (2010). M1 Economic Corridor development study: A report for Fingal, Meath and Louth County Councils. Dublin: Indecon.

International Centre for Local and Regional Development. (2009). The Newry-Dundalk Twin City Region - Supporting the implementation of crossborder collaborative frameworks. Armagh: International Centre for Local and Regional Development.

Irish Academy of Engineering. (2016). Dublin-Belfast Economic Corridor: A European growth hub on the island. Dublin: Irish Academy of Engineering.

Kammerer, M., \& Namhata, C. (2018). What drives the adoption of climate change mitigation policy? A dynamic network approach to policy diffusion. Policy Sciences, 51 (4), 477-513.

Kaucic, J., \& Sohn, C. (2021). Mapping the cross-border cooperation 'galaxy': An exploration of scalar arrangements in Europe. European Planning Studies. doi: 10.1080/09654313.2021.1923667

Kennedy, M. (2000). Division and consensus: The politics of cross-border relations in Ireland, 1925-1969. Dublin: Institute of Public Administration. 
KPMG. (2014). Report on the Lord Mayors' Forum, 28 March 2014. Belfast: KPMG.

Kunaka, C., \& Carruthers, R. (2014). Trade and transport corridor management toolkit. Washington, DC: World Bank.

Kurowska-Pysz, J. (2016). Opportunities for cross-border entrepreneurship development in a cluster model exemplified by the Polish-Czech border region. Sustainability, 8, 230.

Lagana, G. (2020). EU Structural Funds Programmes on the island of Ireland: Interreg and the cross-border dimension. In G. Lagana, The European Union and the Northern Ireland peace process (pp. 105-31). Switzerland: Springer.

Magennis, E. (2007). Public policy cooperation: The common chapter Shadow of substance? In J. Coakley \& L. O'Dowd (Eds), Crossing the border (pp. 245-62). Dublin: Irish Academic Press.

Magennis, E. (2012). The impact of devolution on everyday life, 1999-2010: The case of cross-border commerce. In C. McGrattan \& E. Meehan (Eds), Everyday life after the Irish conflict: The impact of devolution and cross-border cooperation (pp. 117-34). Manchester: Manchester University Press.

Mayer, M. (2008). To what end do we theorize sociospatial relations? Environment and Planning D: Society and Space, 26 (3), 414-19.

McArdle, P. (2013). The Newry-Dundalk twin city region: 10 recommendations for further action. Journal of Cross Border Studies, 8, 71-88.

Mintrom, M. (2019). So you want to be a policy entrepreneur? Policy Design and Practice, 2 (4), 307-23.

Molotch, H. (1976). The city as a growth machine: Toward a political economy of place. American Journal of Sociology, 82, 309-22.

Murphy, M. C. (2018). Europe and Northern Ireland's future: Negotiating Brexit's unique case. London: Agenda Publishing.

Nadin, V., Stead, D., Dąbrowski, M., \& Fernandez-Maldonado, A. M. (2021). Integrated, adaptive and participatory spatial planning: Trends across Europe. Regional Studies, 55 (5), 791-80.

Ó Beacháin, D. (2018). From partition to Brexit: The Irish government and Northern Ireland. Manchester: Manchester University Press.

O’Dowd, L., McCall, C., \& Damkat, I. (2007). Sustaining cross-border cooperation? The public, private and civil society sectors. In J. Coakley \& L. O'Dowd, Crossing the border (pp. 263-87). Dublin: Irish Academic Press.

O'Keeffe, B., \& Creamer, C. (2019). Models of cross-border collaboration in a post-Brexit Landscape - Insights from external EU borders. Irish Geography, 52 (1). doi: 10.2014/igj.v52i1.1376

Perkmann, M. (2007). Policy entrepreneurship and multi-level governance: A comparative study of European cross-border regions. Environment and Planning C: Government and Policy, 25 (6), 861-79.

Quigley, G. (2015). A time to speak. Belfast: Ulster Bank.

Rafferty, G., \& Blair, N. (2020). Emergent cross-border functional geographies on the island of Ireland: Pre- and post-Brexit. Irish Geography, 52 (2), 175-91. 
Roper, S. (2007). Cross-border and local cooperation on the island of Ireland. Political Geography, 26 (5), 554-74.

Rydin, Y. (2021). Governance theories: Stakeholders, networks and collaboration. In Y. Rydin, Theory in planning research. Planning, environment, cities. Singapore: Palgrave Macmillan.

Saldert, H. (2021). Spanning boundaries between policy and practice: Strategic urban planning in Gothenburg, Sweden. Planning Theory and Practice, 22 (3), 397-413.

Schönweitz, M. (2008). The Öresund Committee: Cross-border institution building in the Baltic Sea region. NordEuropaForum, 18 (2), 75-94.

Scott, J. W. (1999). European and North American contexts for crossborder regionalism. Regional Studies, 33 (7), 605-17. doi: 10.1080/ 00343409950078657

Stead, D., \& Meijers, E. J. (2009). Spatial planning and policy integration: Concepts, facilitators and inhibitors. Planning Theory and Practice, 10 (3), 317-32.

Stone, C. N. (1989). Regime politics, governing Atlanta. 1946-1988. Lawrence: University of Kansas Press.

Svensson, P. (2019). Formalized policy entrepreneurship as a governance tool for policy integration. International Journal of Public Administration, 42 (14), 1212-21.

Tannam, E. (1999). Cross-border cooperation in the Republic of Ireland and Northern Ireland. Basingstoke: Macmillan.

Tannam, E. (2006). The European Union 'model' and administrative cooperation: The case of Northern Ireland and the Republic of Ireland. Public Administration, 84 (2), 407-22.

Teague, P., Bew, P., \& Patterson, H. (1997). Northern Ireland beyond war and peace. London: Lawrence \& Wishart.

Tilly, C. (1985). Models and realities of popular collective action. Social Research, 52 (4), 717-47.

True, J., \& Mintrom, M. (2001). Transnational networks and policy diffusion: The case of gender mainstreaming. International Studies Quarterly, 45 (1), 27-57.

Wachsmuth, D., \& Kilfoil, P. (2021). Two logics of regionalism: The development of a regional imaginary in the Toronto-Waterloo Innovation Corridor. Regional Studies, 55 (1), 63-76. doi: 10.1080/00343404. 2020.1817362

Waite, D. (2021). Agglomeration is in the eye of the beholder: The changing governance of polycentrism. Territory, Politics and Governance. https://doi.org/10.1080/21622671.2021.1886978

Walsh, C. (2015). Creating a space for cooperation: Soft spaces, spatial planning and territorial cooperation on the island of Ireland. In P. Allmendinger, G. Haughton, J. Knieling \& F. Othengrafen (Eds), Soft spaces in Europe: Re-negotiating governance, boundaries and borders (pp. 192-212). London: Routledge. 
Williams, B., Berry, J., \& McGreal, S. (2006). The East Coast Corridor: Spatial development strategies for the Dublin-Belfast metropolitan regions. Journal of Irish Urban Studies, 1 (2), 19-31.

Yarwood, J. (2006a). Overview and summary. In J. Yarwood (Ed.), The Dublin-Belfast Development Corridor, Ireland's mega-city region? Aldershot: Ashgate.

Yarwood, J. (2006b). Towards an hypothetical regional plan for the DublinBelfast Corridor. In J. Yarwood (Ed.), The Dublin-Belfast Development Corridor, Ireland's mega-city region? Aldershot: Ashgate.

Zimmerbauer, K. (2018). Supranational identities in planning. Regional Studies, 52 (7), 911-21. 